\title{
THE HISTORY AND DEVELOPMENT OF GAMAT MUSIC AS A PROTOTYPE OF BANDAR ART IN THE WEST SUMATERA COASTAL AREA (PESISIR)
}

\author{
Martarosa $^{1}$ \\ ${ }^{1}$ Studies Program, Faculty of Performing Arts ISI Padang-panjang \\ Email: martarosa64@yahoo.co.id
}

\begin{abstract}
At the end of the 19th century and the beginning of 20th century, the city of Padang has been dubbed the metropolis of the island of Sumatera. This is because the population of the Europeans who live there is relatively higher than other cities in Sumatera. An influence of this condition appears to be the phenomenon of Western-style music which was introduced to the indigenous peoples (Bandar natives). The appropriation of this musical style from various cultures such as of Portuguese (European), Malay and Minangkabau eventually became known as Gamat. Nowadays, the well-known Gamat is part of the identity of the culture, especially for Minangkabau in the West Sumatera coastal area.
\end{abstract}

Keywords: Prototype, Bandar art, Gamat music, the West Sumatera coastal area.

\section{INTRODUCTION}

Gamat music, also known as Gamaik, is one of the various musical performance arts which arose and developed as the typical art and culture of the indigenous Minangkabau people of Western Sumatra. The difinition the word Gamat in the Kamus Besar Bahasa Indonesia in Language Center (2014: 409) is a song or rhythm, and, menggamat means touching with fingers as signal, Navis (1984: 276) defines the epistemology of the word Gamat as coming from the functional word gamit. The real meaning of the activity menggamit or beckoning in Gamat music literally means giving a shawl or a handkerchief to the performer or audience in order to ask them to dance. Based on that verb gamit or beckon, Gamat was chosen as the name of this performance art.

Due to the activity of giving a shawl or a handkerchief, Rizaldi (1994: 54) said that Gamat music performance tradition is usually followed by the spontaneous dancing of two to four people with the combination of free movement dance, facing the Gamat singer/vocalist. The shawl or handkerchief is used only as additional equipment to lay on someone's body. For the audience member receiving the shawl or handkerchief, he or she is asked respectfully to dance in the performance. One interesting point is that, in the context of performance art, there is no name for the dancer of Gamat music. In other word, the available term is only Gamat music performers as the instrumental music performer as well as the vocalist. However, Gamat vocalists are typically able to dance spontaneously and freely, both in the form of live dance (joget) or classical melody (langgam).

Based on the descriptions above, it seems clear that in general Gamat music performance is a combination between the genre of instrumental music and vocal music followed by spontaneous 
dances, both in the form of live dance or melody. It is done by vocalists and audience members in the movements which are free and monotonous. A unique characteristic combination between some different types of arts, furthermore, presents the indication of cross-cultural. It is assumed that the rise and development of Gamat music as the culture and art of the indigenous people of Minangkabau in the West Sumatera coastal area, as well as other similar Malay Peninsula music, occurred as the result of symbiotic relationships in the cultural interaction between the Portuguese, the Malay and the Minangkabau (Martarosa, 1999: 125). The form of cross-cultural interaction also has been predicted as having resulted in various kinds of different music in the many cultural realms, for instance, Dondang Sayang music in the neighboring Malay Peninsula, Ghazal music in the Riau archipelago and North Sumatra, and Ronggeng music in West Sumatra and North Sumatra.

Thus, Gamat music is the result of the process of mutual cross-cultural influence in the area of Minangkabau, West Sumatra, especially whit in the culture of people who live in the coastal area. The presence of Western (Europe Continent), musical instruments for example, violin, accordion and guitar in Gamat music indicates the influence of European culture. It is known that the Portuguese introduced those musical instruments and the Malay, sailors brought them and bore the art of "Bandar" (the city of ports). The difference of Gamat music between regions, meanwhile, can arise from the presumption that the offering of Gamat tradition is influenced by European culture and not always accepted in every cultural region as what it is. This musical difference in every region indicates that there is an adaptation process due to the matter of the acceptance of cultural elements from the outside to inside of the local culture itself. In other words, Gamat music can be seen as a type of hybrid music. It rose and developed through the appropriation process by which Gamat music was accepted by Minangkabau people.

Further analysis about the appropriation process, can be understood from historical observation. Sartono Kartodirdjo (2014: 338-340) emphasizes it is important to see whether the present situation is the result of the changeable occurrence or the product of development in the past. Based on this statement, this research aims to consider the hypothesis that the initial interaction process in cross-cultural music brought a prototype of Gamat music to bear. It is also important to know the exact time when Gamat music started to develop, and how the process of various changes in Gamat music as the culture of native people of Minangkabau in the West Sumatera coastal area still remains to the present day.

This research has tried to clarify historically the forming of the Gamat music prototype by narrating the reconstruction of past events through facts which relate to what, who, when, and where, Sartono Kartodirdjo (2014:1). Said that the use of observation in mixed with historical perspective can be a consideration; first, to help understanding the mutual cross-cultural relationship by which Gamat music is produced; second, to comprehend the relationship between Gamat music as the developed product of recent culture and art, and the cultural dynamic background of the past. Hopefully this analysis can be used to predict its development in the future. The existence of Padang in the past as Bandar - the city of ports - it considered to be a main factor in the development of Gamat music. In conclusion, Gamat music can be seen as the realization of Bandar art in the matter of Minangkabau people in the West Sumatera coastal area at the beginning of the 20th century.

\section{DISCUSSION}

\section{The Birth of the Gamat Music Prototype as the Realization of Bandar Art at the Beginning of 20th Century}

Since the colonizers first settled in the city of Padang, the natives there received much appreciation in art because of their multiculturalism. Zainal Arifin (2012: 32) states that, eventhough the Minangkabau people are customarily obedient and rule-abiding, all of their daily life activities are regulated properly. This can strengthen the statement that throughout the 19th century Padang was dubbed as a metropolis city in Sumatra region. In spite of the fact that the of European population there was relatively greater than other cities in Sumatra.

It started when the European allies, such as Belgium, Germany, France, Switzerland, etc. were getting involved to help the Dutch army in 
the Pidari War, in West Sumatra. When the War ended, many of them stayed because of many reasons. First, Padang city was considered to be a public administrative city of the Dutch Colonial government in West Sumatra and this condition provided opportunities for them to trade in many sectors. Second, they were interested in padang women. Many of them married the local girls or other Dutchwomen who were living for such a long time in Padang city other Europeans. Last but not the least, many of them left their duties as Dutch soldiers and lived in Padang city.

The Dutchmen who assimilated in Padang city, were categorized as Eurasian people. As Europeans who were living in Padang, the Dutchmen named themselves Indische Nederlanders. At that time, Padang had grown as the city located outside the Java Island with the large population of Eurasian and Indische Nederlanders (Rusli Amran, 1988: 59). As already mentioned above, a lot of native and Nias tribe descendants married the European men or other Europeans soldiers under Dutch supervision in Padang city. Rusli Amran which emphasizes this:

“ ... a person whose well-known as Jeans Baptiste Belloni, born in Belgium. ... once served in Padang and married a local woman whose name Nasrani. This name changed into Maria Magdalena. They had a son named F. H. Belloni..., the little Belloni lived and married in Padang. ... Pleace notice that many Eurasian people marry with the Nias descendant girls" (1988: 78).

The interactional relationship within ethnicities and cultures in Padang city seems clear since the 19th century because Padang is a living city of native Minangkabau also other ethnicities, such as Javanese, Nias, Chinese, Arab, Tamil Indian, Japanese, European and Eurasian or Indische who had been already registered as citizens of Padang (Rusli Amran, 1988: 307). Since from the beginning, the culture of Padang city was likewise multi-cultural, these communities assimilated and influenced to each other. Especilly in the art sector, where the various arts from ethnicities living in Padang were able to interact with European arts supported by Eurasian citizens or Indische Nederlanders.
In the next period, the rapid development of Padang city occurred after the Emmahaven International Port was officially opened and operational in 1892. Suryadi (2003: 53) states that since the Port operated in the end of 19th century to the beginning of 20th century, many big company offices were set up. They involved, first, the private trading enterprise offices like Houten Steffan, Guntzel \& Scumacher, Veth, Geo Wehry, Jacobson van den Berg, Tels \& Co, International etc.; second, hotels like Hotel Oranje, Hotel Pension, Hotel Sumatera, Hotel Padang, Hotel Central and Aceh Hotel; third, entertainment and art performance places such as Clubhouse like De-Eendeacht (unity), Burger Societeit (only for civil) and Societeit Ons Genoegen (our happinesss) which were restated to Europeans, Coloured-skin Eurasians and also the lower soldiers; fourth, big stores like Kranich Shop, Japan Toyo Shop, Otani Shop and Sakura Shop; fifth, cinemas like Scale Bio, West Sumatera Bioscope, Aurora, Variete, Vesta, Awaq and Cinema Theater (Rusli Amran: 13-27).

At the same time, however, the opera house was built in order to be a site for art performance in Padang city. The group of people who performed at that building included: Indra Bangsawan Group, Sri Dermawan Group, The Group of Indra Tjahaja Ratoe Comany, Komedi Kasim Group and Sri Sumatera Group. Various famous narrative titles were performed at those comedy houses, such as "Djoela Djoeli Bintang Tiga or The Three Star of Jula Juli", "Si Tjonat or Conat The Bandit", "Nyai Dasima or Madam Dasima", "Djohan Arifin," and other story us from "1001 Arabian Nights". The rise of those groups of performers made the opera popular in the late of 19th century and the beginning of 20th century in Padang city.

The popularity of the operas in Padang city is not only because of the full support from the native Minangkabau and other ethnicities but the Chinese and Eurasian people also contributed to its glory. For example, one well-known Eurasian actors at that time was Auguste Machieu. However, the support from Colonial higher rank officials such as the assistant of a residency in the colonial administration, the governor and his secretary, and other famous people involved as the actor or actress and as the audience (Rusli Amran: 13- 
27). Suryadi (2014: 62) quoted from Ch. E.P. van Kerckhoff in his article "Het Maleisch Tonnel ter Weskunt van Sumatera" published in the journal of Tijdshrift voor Indischi Taal-, en Volkenkunde (31(1886): 302-14) that in the end of the 19th century, in Padang city, the life and development of art like dramatic art and music art rapidly grew.

The opening gate of Bayur Bay Port as an international trading way made possible the flow of information and goods from other regional areas such as Batavia (Jakarta), Semarang, Surabaya, Singapore, Penang, the Middle East and Europe. Suryadi (2014:54) clarifies based on the information from Sumatra-Courant published on August 30, 1898 that kinds of imported modern goods from Europe had been sent to Padang. One of them was Phonograph or known as Gramophone which is an old recorder and vinyl record player. In Indonesia this equipment was demonstrated for the first time in Padang, 1898 and distributed to sell in Java.

It is not surprising that in the beginning of the 20th century in Padang, there was so much trade of this talking equipment, whether advertised through the radio or the Dutch of and local newspapers. Gramophones and the vinyl record were usually for sale. These goods commonly belonged to the European and Eurasian people, higher rank government officials and also successful entrepreneurs. The vinyl diskes or records were usually contained song material whose composition derive from European instrumental music, such as classical music and romance by Schubert, Schumann, Chopin and Mendelssohn. However, there were also the vinyl disks or records with local Javanese music, Keroncong songs and operas and sold in West Sumatra at that time (Suryadi, 2014: 54). Thus, the people of Padang city in the early of 20th century were able to appreciate Western classical music, Keroncong songs and the audiorecorded opera performances through vinyl disks or records and gramophones.

The statement above can be related to the previous statement about the early 20th century Belgian soldier named Jean Baptiste Bellony, who married a Nias woman named Nasrani, who became a Padang citizen and changed her name Maria Magdalena and gave a birth to a son named F. H. Belloni. Moreover, F. H. Belloni is a musician who was half Indonesian half and European, a Padang citizen, born in 1891. His ability in music was proved in the below quotation:

"Every Keroncong fans must have heard Belloni. He is known as the first person who is written and composed Keroncong music on the piece of paper surface. He is also the first man playing Keroncong in the big orchestra at Bandung, at the big precious hall also, full of white-skin nations. He is completely success. In the present century his name is be able to read on many vynil records. It exists truly because of Belloni's praiseworthy achievements, who was born in Padang 1891 (Rusli Amran: 78).

Based on the above statement, it can be concluded that Padang is a coastal city occupied by many immigrants from various nations, not only the native Minangkabau. This allowed for a hybrid art that reflected its multicultural population. One form of that hybrid art was Gamat music which still remains. In other words, the Malay performance art which was popular in the Colonial era amused the public on many occasions at the in Padang city. The Eurasians in Padang city had their own Keroncong musical group (Suryadi, 2011). In the first quarter of the 20th century, there existed a number of musical groups. It can be seen as a prototype or the early step of the rise and development of various local musical groups in Padang. The musicians in general came from Europe. This kind of music was named 'Muziekclub Petit Advendo' which is a combination of French language ('Petit', means short and small), and a Dutch acronym ('Advendo' or Aangenaam Door Vermaak En Nuttig Door Ontspaning which means a pleasure of bliss and a relaxation benefit). This kind of musician group commonly performed in many elite nobleman parties in Padang at that time. The musicians from the local and European musical group are seen below: 


\section{Picture 1}

Muziekclub Petit Advendo group in Padang in the early quarter 20 th century

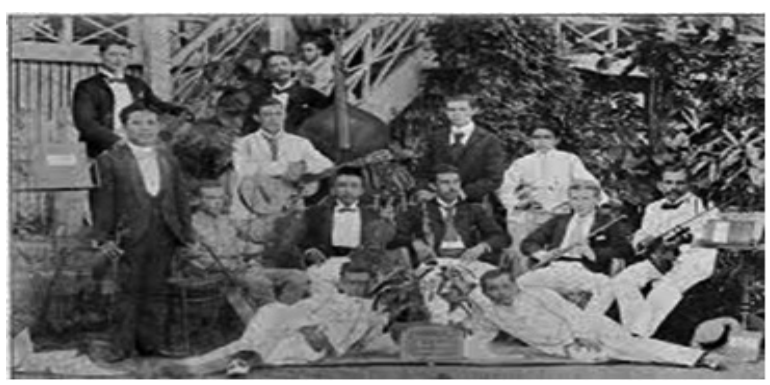

Photo source: KITLV in Suryadi Singgalang,

Monday June 19th, 2011 (Photo: Suryadi)

In the picture above, the common musical instrument are used by the Muziekclub Petit Advendo in Padang are violin, guitar, flute, double stringed bass and some blow instruments. The local and European musicians are in formal clothes, quite neat in a white and black suit and wearing ties.

\section{Picture 2}

A Europe an musical group in Padang city in the early 20th century wearing white suits

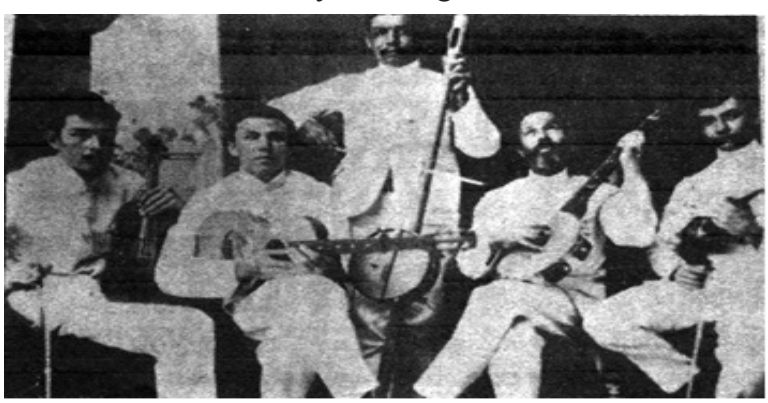

(Photo Rusli Amran: 316)

Rusli Amran in his book entitled Padang Riwayatmu Dulu (Padang in Past Event), also serves about the photos of this musical groups in Padang in the early 20th century. In the next picture, the musical instruments used are two violins, a flute, a tom-tom drum, a tambur, castanets or tambourine. The most interesting aspect of the picture is that the local musicians do not blend together other European musicians and they are not wearing suits and ties. This condition indicates that the early quarter 20th century, the local music groups existed as performers of Padang music art like the picture below.

Picture 3

A musical group in Padang city in the early 20th century whose all personnels are not Eurasian

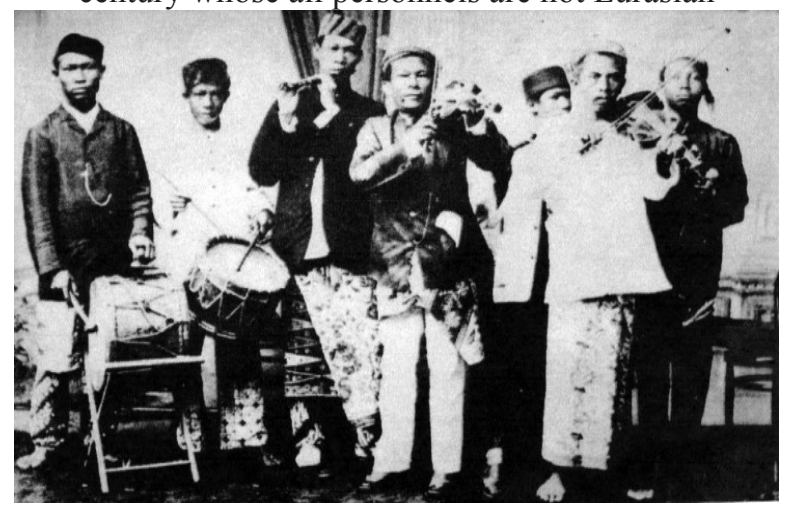

(Photo: Rusli Amran: 192)

A great presumption lies in a decade in the early 20th century in Padang city. Take a look at the picture above; the presentation of percussion, tambour and drums sets as the unique style and characteristic of Gamat commonly has functioned as an accentuating confirmation in the form of music for a dance accompaniment. It that Gamat is a form derived from the transformational process both in the music and the dance presented by Portuguese people and, therefore, is the beginning process of the existence of Balanse Madam dance. This dance is still supported to this day by the Nias people living in Padang city. Indrayuda (2008: 4) states that the descendants of Balanse Madam dance are considered to be a creative form which adopted the Portuguese's dancing. An a matter of fact, he adds that the creation of movement patterns do not derive from the Portuguese's dancing movement but from the Nias alike Maena and Hiwo. Those movements were then combined with Malay dance movements because at the same time the Malay dance was also popular among the urban noblemen all over the coastal region of Sumatra. 


\section{Picture4}

An orchestra group Irama Muda (young rhythm) in Padang city 1955, with a Minang composer, the late Yusaf Rahman (Mr. Cap) number two from right position holding a violin instrument

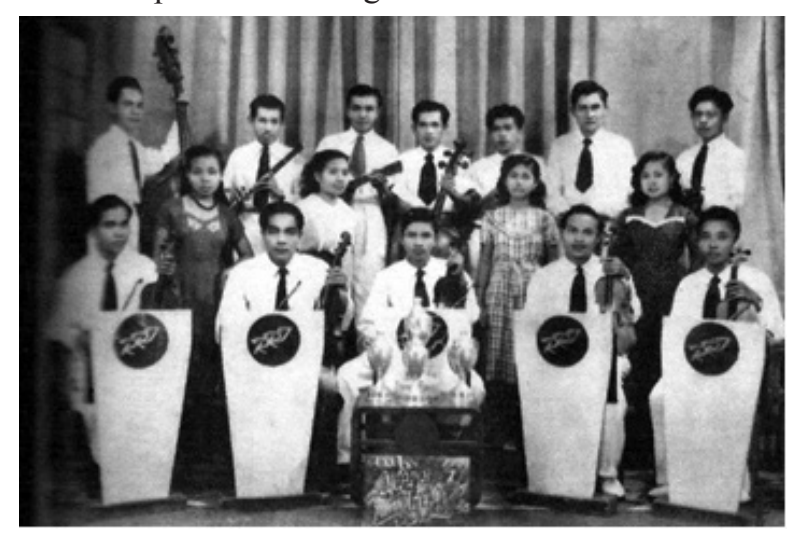

(Photo: Nazif Basir, 2007: 167).

A reflection from the Balanse Madam case, the origin of the rise and development of Gamat music in the West Sumatera coastal area, it that the early introduction was brought by Portuguese perple through Malay sailors. That music is known as Bandar art because its popularity exists at the cities where the ship was berthed, and it was commonly celebrated for the ship crews amusement. This music had the same value with Joget (live music dance) from Malay art. It can be an indication that the Portuguese culture influenced the use of violins and the visibility of one song entitled "Kaparinyo" in Gamat tradition (A.A. Navis, 1982: 96-97).

It is a fact that in the end of the 19th century up to the early of 20th century, the passion for art activity in Padang city grew rapidly. This condition then motivated local music groups in the next decade to form groups, for instance, The Smiling Hawaiian Orchestra established in 1938 by Asbon Madjid (Suryadi, 2014: 126). That music group at that era held a live performance in Padangsche Radio Omroep and in the radio NIROM Medan. During the Japanense colonialization, Asbon was chosen to be a Piston player in the Musical Corps of the Dai Nippon Army in Padang.

Rizaldi (1994: 135) defines that around 1920 the rising and development of Gamat music in Padang city, same as Gambus and Keroncong, exists and its role as the local culture is not quite sturdy. Gamat is well-developed widely in Padang after 1930 but still in the level of pre-interaction which the main element is still on the adaptation and negotiation process with local music culture. For the conclusion, it can be a cultural identity of local people in Padang.

The Rise and Development of Gamat Music as the Realization of Bandar Art in the West Sumatera coastal area Nowadays.

The development of Gamat music in Padang city became an influence to many coastal areas in the South of West Sumatra, for example at Koto XI subdistrict, Tarusan district, and the Southern Coastal area. Geographically, Padang and Tarusan are located closely in the same coastal area which is called Rantau in the Minangkabau Coastal area. They have a relatively similar culture (Martarosa, 2008: 31). A Gamat musical group is called 'Muda Setia'. The available musical instruments are violin, harmonium, accoustic guitar, double drum, tambourine and vocal.

Despite the existence of Gamat music at that time, the local people still did not consider it as their own culture so that it was performed for the satisfaction and amusement of the musicians and their families. It was not yet used for ceremonies or any rituals, as it is today. Thus the beginning step of the rise and development of Gamat music in the subdistrict Koto XI, and Tarusan is an inheritance from the previous artists or the youth of that local people. At that time, theyperformed as workers and students (Martarosa: 32).

The rise of Gamat music in the native Minangkabau culture especially in the West Sumatera coastal area encouraged the development of Minang songs as local culture especially after the independence time. It is indicated, for instance, through the Minang song Kampuang Nan Jauah Di Mato (faraway from the hometown) popularized by Oslan Husein throughout musical group named "Teruna Ria" in the late 1960 . The development was supported by other musical group, i.e. Gumarang Orchestra lead by Asbon Majid, Kumbang Tjari Orchestra lead by Nuskan Syarif and Zainal Combo Band lead by Zaenal Arifin. The Minang songs became popular at that time as the great product of the first local culture in Indonesia and packed in the rock rhythm also within Minang pop label as a prototype of localized pop songs, (Victor Ganap, 2008: 12). 
Gamat music nowadays has developed widely among natives of Minangkabau. It develops in Padang and other coastal areas in the Southern region of West Sumatra and it is supported not only by native Minangkabau but native Nias and Indian Keling who are citizens of Padang city. The music was, first, performed as an amusement for ship crew or sailor at the port; second, set up through the interaction between the Malay sailor and the native of Minangkabau, Nias and Keling; and third, continously developed and adopted people in the coastal and mainland areas of Minangkabau.

Bandar art considers to be an art of the port city generally having its unique characteristic and its structural music form relatively the same. Based on Asnam Rasyid (interview, August 30th, 2015), Gamat music generally has the same feature like the other music types in other Bandar like Keroncong, Gambang Kromong, Ronggeng and Gazal. Instead of the sameness of instruments used by them, the sameness also exist in the context of Portuguese and Dutch influences. It can be seen also that the sameness of visibility on the musical characteristics and performance form structure involves: intro, main song, interlude and coda.

Based on musicological observations about the results of re-recording Gamat music in the 1960s in Padang city, the type of musical instruments commonly used are violins, acoustic guitars, double stringed bass, double drum, tambour, castanets and tambourine. Gamat songs were still performed acoustically (non-electric) both in the form of Langgam (melody) or Joget (live dance). Moreover, the use of the accordion as the musical the musical accompaniment to the vocal in Gamat music, has not been found.

The interesting point is that the function of the double stringed bass, as the accompaniment music for the vocals does not tend to play progressive chords horizontally in every part of the song, but tends to function like a percussion instruments with the double drum as an additional accentuation.
The double stringed bass is always played in the form of one chord only based on the base tone of the chosen song. Also, the function of the guitar as the accompaniment of the vocal music must be the same with the chord fraction like in Keroncong.

In the 1970s, specifically 1974, it electronic music became popular in Padang city, for instance the electric guitar, electric bass and other electrical sound systems both for musical and vocal instruments. The presence of this modern set influenced the changing of style and form to play orchestra as what found previously is in the form of pure acousticl music. Nowadays even the of double stringed bass is rarely played because it seems to make an imbalance sound with other electrical instruments. Below is the picture of almost all Gamat musical instruments using electrical sound system. Those instruments are violin, electrical melody guitar, accordion, electrical bass guitar, double drum and tambourine. It means that the presence of technology of electrical music instrument was rapidly incorporated by the Gamat artists in Padang city. Furthermore, the Gamat artists easyily changed the form of music instruments due to the development of music instrument technology. The impact is that Gamat music nowadays has been changed to become semi electrical music like other popular music where music instruments transformed from pure accoustic to be more electric.

The following pictures will show the form and kinds of music instruments used by a Gamat music group in Padang recently, whose members an citizens of Padang and come from Minang, Nias and Keling descendants. In the next picture, there is a Keling singer who is tall and dark skinned, as the vocalist of Gamat music singing live in the one of radio stations in Padang. Meanwhile, in another picture, there is a female Gamat music singer who comes from Nias and is a citizen of Padang, singing live in one of the radio stations in Padang. 
Picture 5

Form and kind of music instruments used by a Gamat music group in Padang recently

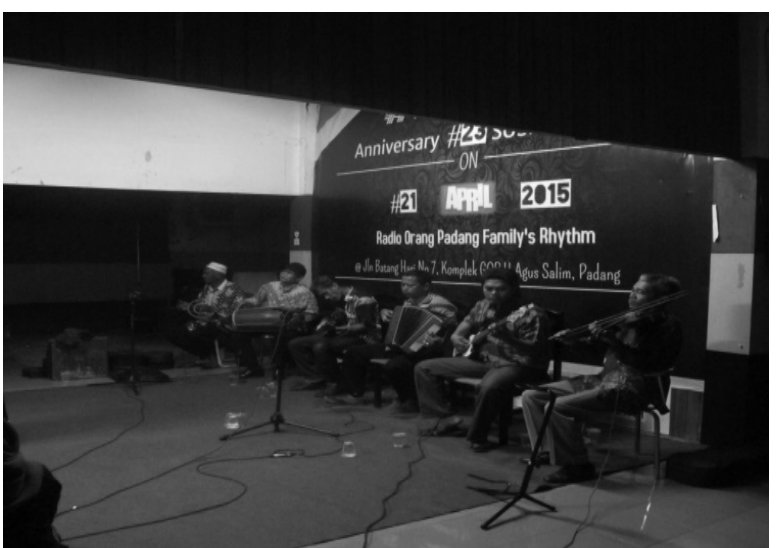

(Photo: Martarosa, Padang, July 31st 2015)

Picture 6

A Keling singer as the vocalist in Gamat music is live on one of the radio station in Padang city

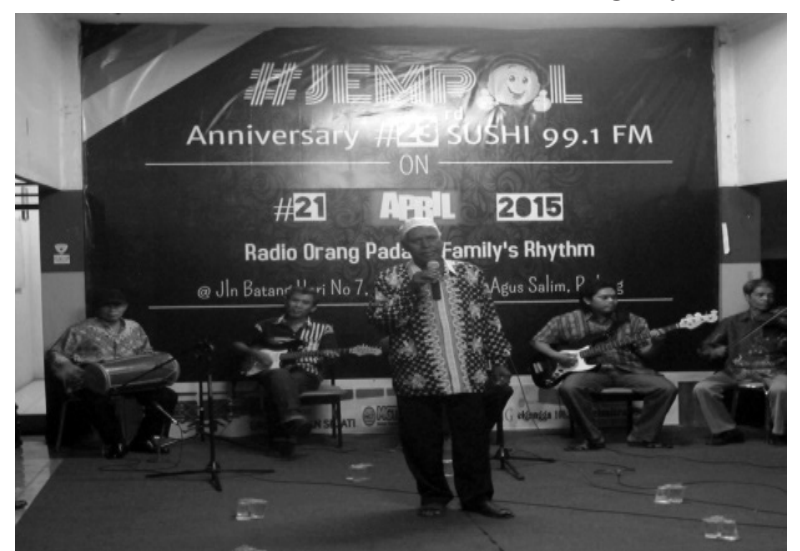

(Photo: Martarosa, Padang, July 31st 2015)

Picture 7

A female singer of Gamat music from Nias, and a citizen of Padang, is live on one of the radio station in Padang city

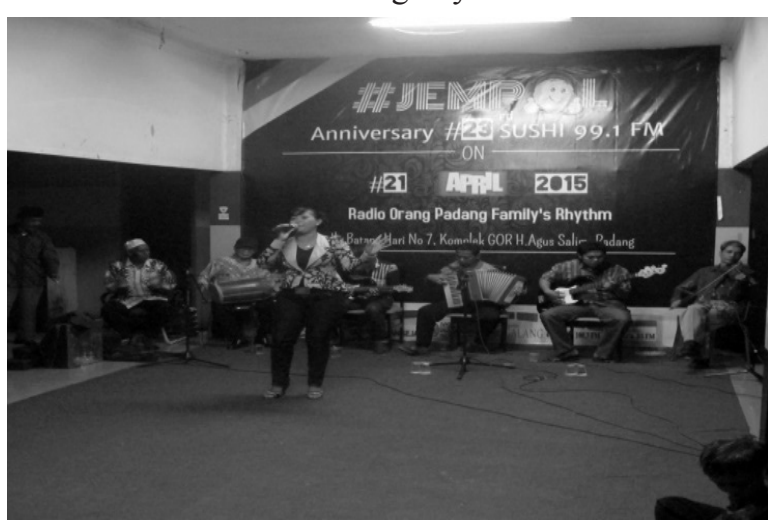

(Photo: Martarosa, Padang, July 31st 2015)
In the 1980s in Padang city with the existence of electrical organ music instrument, some Gamat music group in Padang also changed the formation of Gamat musical instruments other. There are electrical organ, accordion, double drum, tambourine, vocal and sometimes plus woodwind instruments like the tenor saxophone. The use of technology of electrical organ tends to produce a new nuance to various sounds of musical instruments like electrical bass, electrical melody guitar, violin and percussion. These formation of Gamat musical instruments seem to produce a nuance of different music serving while the previous form is more acoustic rather than electric.

This formation of musical instruments like this is favourable to many Gamat musicians both senior and junior in Padang. It happens because this formation does not bind them and enables them to adapt both in the electrical instrument form and in the form of pure acoustic. Below is the picture of some vocalists of Gamat music in Padang city singing in the one of ritual wedding occasion malam jago-jago (stay awake in the night) at Ampang Pulai, Tarusan disctrict, Koto XI Tarusan subdistrict, Southern Coastal area. There is also the another picture of a Keling singer singing a duet with another local Gamat singer in the form of Langgam and Joget, saying Pantun (traditional rhyming slang) while the shawl is around his neck, at Ampang Pulai Tarusan, Koto XI subdistrict, Tarusan district, Southern Coastal area.

\section{Picture 8}

Some vocalist of Gamat music singing in the one of ritual wedding occasion malam jago-jago (stay awake in the night) at Ampang Pulai, Tarusan disctrict, Koto XI Tarusan subdistrict, Southern Coastal area

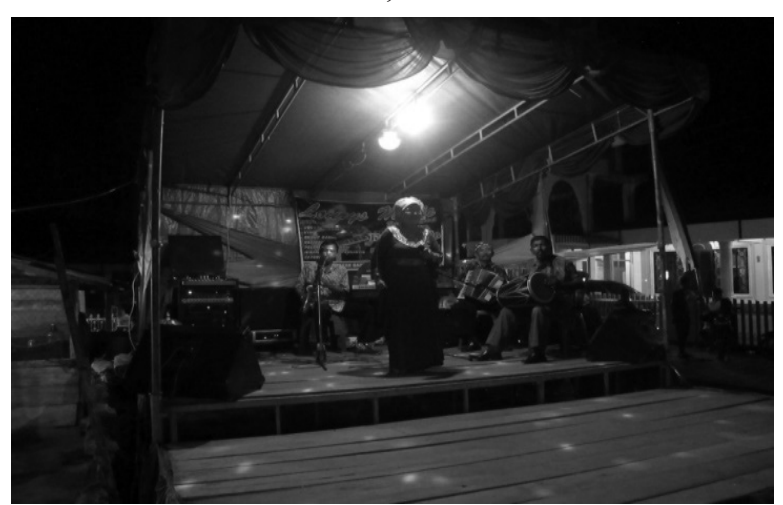

(Photo: Martarosa, Ampang Pulai, Tarusan, May 23rd 2015). 


\section{Picture 9}

A Keling singer singing duet with another local Gamat singer in the form of Langgam and Joget, saying Pantun (traditional rhyming slang) at Ampang Pulai Tarusan, Koto XI subdistrict, Tarusan district, Southern Coastal area

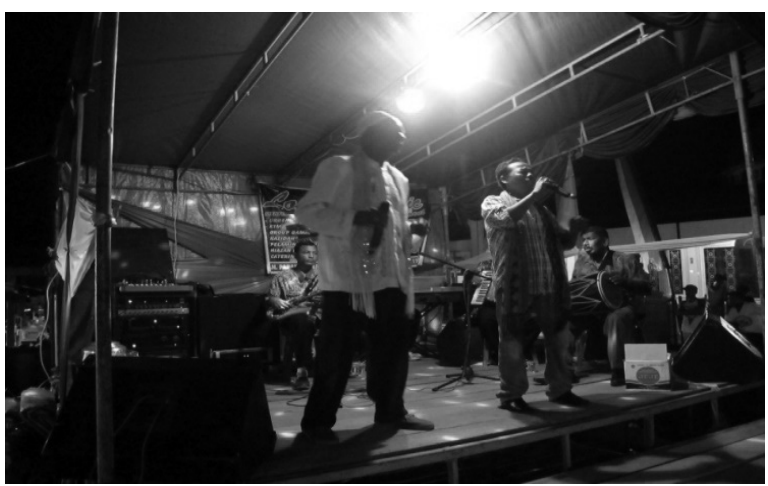

(Photo: Martarosa, Ampang Pulai, Tarusan, May 23rd 2015)

\section{Picture 10}

A Gamat music group GurindamPasisie at Ampang Pulai Tarusan is in rehearsal. The music instruments used involve violin, electrical melody guitar, double drum, tambourine and vocal. The musicians are the native people there

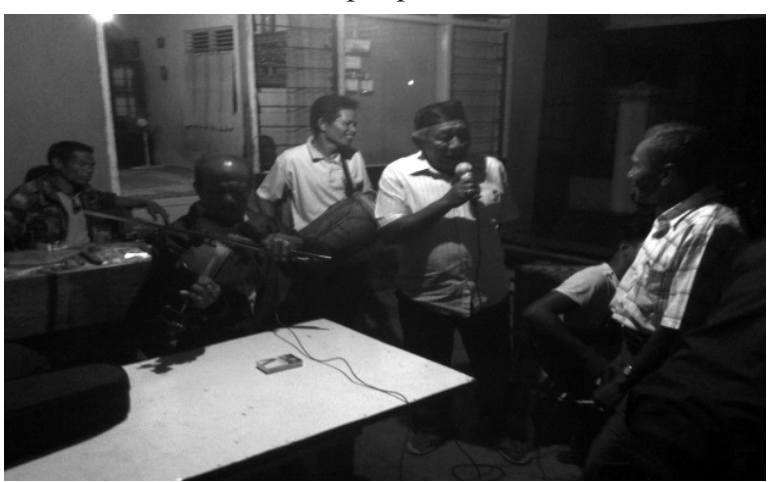

(Photo: Martarosa, Ampang Pulai, Tarusan, August 12nd 2015)

\section{CONCLUSION}

The historical facts that show Padang city in the late 19th century and in the early 20th century developed and became the main Bandar and was dubbed as a "metropolitan" city in Sumatera. It gives a clear description about the development of Gamat music as Bandar art. The existence of Eurasians gave an opportunity for the introduction of Western style musics to the local people. The beginning process of Gamat music tended to be from music which belongs to Portuguese (European) through Malay sailors. This presumption underlines that Gamat music is the product of cultural appropriaton of music. It was not suddenly received by the local people in the coastal area of Minangkabau when the Malay sailors introduced it for the first time. Rather, Gamat music grew and developed as Bandar art which was influenced by various musical elements both from European culture and local culture.

This European style music then transformed through the musical appropriation process because of the influence of Portuguese (Europe), Malay and Minangkabau cultures. Then, Gamat music became a part of the identity of local Minangkabau in the Sumatera's Western Coastal area. The development of Gamat music as the local culture of Minangkabau in the Sumatera's Western Coastal area occurred because of the people supporting Gamat music in the appropriation and development of music technology. However, the existence of one musical culture can influence another so that the Gamat music is the local culture of Minangkabau in the Sumatera's Western Coastal area. It is different from other Malay musics as the art of their own Bandar cities.

\section{BIBLIOGRAPHY}

Arifin, Zainal. (2012). "Buru Babi: Politik Identitas Laki-Laki Minangkabau" in Humaniora (Jurnal Budaya, Sastra, dan Bahasa) Yogyakarta: Fakultas Ilmu Budaya Universitas Gadjah Mada.

Basir, Nazif. (2007). Yusaf Rahman: Komponis Minang, Bandung: Lubuk Alung.

Departemen Pendidikan Nasional. (2014). Kamus Besar Bahasa Indonesia Pusat Bahasa, Jakarta: Gramedia Pustaka Utama.

Ganap, Victor. (2008). "Sumbangsih Ilmu Pengetahuan Musik Dalam Pembentukan Jatidiri Bangsa", the article is presented in the front of Senate Plenary Session in the Indonesia Art Institute in Yogyakarta in January 19th

Indrayuda. (2008). Tari Balanse Madam:Pada Masyarakat Nias Padang Sebuah Pesspektif Etnologi, Padang: UNP Press.

Kartodirdjo, Sartono. (2014). Pendekatan Ilmu Sosial Dalam Metodologi Sejarah, Yogyakarta: Ombak.

Martarosa. (1999). "Musik Gamat Sebagai Musik 
Prosesi Dalam Budaya Masyarakat Kecamatan Koto XI Tarusan Pesisir Selatan Sumatera Barat" Tesis Universitas Gadjah Mada.

. (2008). "Musik Gamat Dari Pertunjukan Pentas Ke Seni Pertunjukan Prosesi (Sebuah Tinjauan Historis)" in Jurnal Ekspresi Seni Vol. 10, 1 Mei 2008, Padangpanjang: Pusat Penelitian dan Pengabdian pada Masyarakat STSI Padangpanjang

Navis, A.A.. (1984). Alam Terkembang Jadi Guru. Adat dan Kebudayaan Minangkabau, Jakarta: Grafitipers.

(1982). "Seni Minangkabau Tradisional Sumbangan Budaya Dalam Pembangunan, Jakarta: Depdikbud Nasional," in the Cultural Analysis.

Rizaldi. (1994). "Musik Gamat Di Kotamadya Padang: Sebuah Bentuk Akulturasi Antara Budaya
Pribumi Dan Budaya Barat", Tesis Universitas Gadjah Mada.

Suryadi. (2003). "Minangkabau Commercial Cassettes and the Cultural Impact of the Recording Industry in West Sumatra" in ASIAN MUSIC Spring/Summer, Volume XXXIV, number 2.

. (2015). "Minang Saisuak" Singgalang, Sunday, June 19th, 2011. Visit; http://www. goodreads.com/author_blog_posts/1306129minang-saisuak-54---sebuah-grup-musik-daripadang, accessed in September 27th.

\section{INFORMANTS}

Asnam Rasyid, Interview (Padang, Agustus 30th, 2015). Hasnam Rasyid is also an artist and ex-head of Padang Culture Park

Casset Tape HDX, Sinar Padang Record, Martarosa's documentation. 